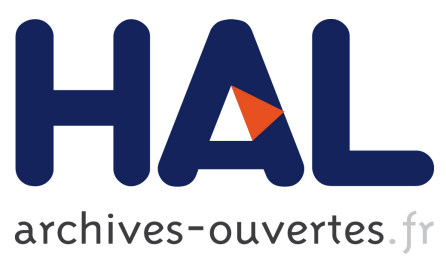

\title{
Effects of foliar application of a byproduct of the two-step olive oil mill process on maize yield
}

Manuel Tejada, José Gonzalez

\section{To cite this version:}

Manuel Tejada, José Gonzalez. Effects of foliar application of a byproduct of the two-step olive oil mill process on maize yield. Agronomie, EDP Sciences, 2003, 23 (7), pp.617-623. <10.1051/agro:2003041>. <hal-00886219>

\section{HAL Id: hal-00886219 \\ https://hal.archives-ouvertes.fr/hal-00886219}

Submitted on 1 Jan 2003

HAL is a multi-disciplinary open access archive for the deposit and dissemination of scientific research documents, whether they are published or not. The documents may come from teaching and research institutions in France or abroad, or from public or private research centers.
L'archive ouverte pluridisciplinaire $\mathbf{H A L}$, est destinée au dépôt et à la diffusion de documents scientifiques de niveau recherche, publiés ou non, émanant des établissements d'enseignement et de recherche français ou étrangers, des laboratoires publics ou privés. 


\title{
Effects of foliar application of a byproduct of the two-step olive oil mill process on maize yield
}

\author{
Manuel TEJADA ${ }^{\text {a* }}$, José Luis GonZALEZ ${ }^{\mathrm{b}}$ \\ ${ }^{a}$ Departamento de Cristalografía, Mineralogía y Química Agrícola, E.U.I.T.A., Universidad Sevilla, Crta Utrera km 1, 41013 Sevilla, Spain \\ b Departamento de Química Agrícola y Edafología, Universidad de Córdoba, Campus de Rabanales, Edificio C-3, Crta N-IV-a, km 396, 14014 Córdoba, Spain
}

(Received 2 April 2002; accepted 16 May 2003)

\begin{abstract}
The main objective of this work was to study the effect of foliar fertilization at different doses with a byproduct of the two-step olive oil mill process on the productivity and quality of maize crops (Zea mays, L. cv. Tundra) located in Lora del Río, near Sevilla (Andalusia, Spain). Foliar fertilizer was applied four times during the season and three different concentrations were tested. Foliar fertilization increased leaf soluble carbohydrate contents, chlorophyll $\mathrm{A}$ and $\mathrm{B}$ and carotenoids, and increased the leaf concentrations of $\mathrm{N}, \mathrm{K}, \mathrm{Fe}, \mathrm{Mn}$ and $\mathrm{Zn}$. Yield was significantly increased by $24 \%$ to $14.9 \mathrm{t} \cdot \mathrm{ha}^{-1}$ by the highest dosage of the byproduct, which also caused a $22 \%$ increase in kernel number and a $19 \%$ increase in grain protein content.
\end{abstract}

oil mill byproduct / olive oil / foliar fertilizer / maize

Résumé - Effet sur le maïs de l'application foliaire d'un sous-produit du processus d'élaboration de l'huile d'olive en deux étapes. L'objectif principal de ce travail était d'étudier l'effet de la fertilisation foliaire à doses différentes avec un sous-produit du processus d'élaboration de l'huile d'olive en deux étapes sur la production et qualité de la récolte du maïs (Zea mays, L. cv. Tundra) dans la région de Lora del Río, près de Séville (Andalousie, Espagne). L’engrais foliaire a été appliqué quatre fois pendant la saison et trois concentrations différentes ont été testées. Cet engrais a augmenté les niveaux d'hydrates de carbone, de chlorophylle A et B et de caroténoïdes et des éléments nutritifs $\mathrm{N}, \mathrm{K}, \mathrm{Fe}, \mathrm{Mn}$ et $\mathrm{Zn}$ dans la feuille. Le rendement a été augmenté de $24 \%$ et a atteint 14,9 t·ha ${ }^{-1}$ avec la dose la plus élevée de sousproduit et s'est accompagné d'une augmentation de $22 \%$ du nombre de grains et de $19 \%$ du contenu en protéines du grain.

sous-produit d'huilerie / huile d'olive / engrais foliaire / maïs

\section{INTRODUCTION}

The dynamics of plant nutrient uptake are quite complex and dependent on crop growth stages. There is a time lag between fertilizer application and the uptake of applied nutrient by plant roots. For this reason, the use of foliar fertilizing in agriculture has been a popular practice with farmers for supplying the nutrients that the plant requires in the early stages of development. In this respect, recent studies have shown that a small amount of nutrient (nitrogen, potash or phosphate) applied by foliar spraying can increase the yield of crops significantly $[1,2,4,8,11,19,30,37]$.

Foliar fertilization does not totally replace soil-applied fertilizer, but it does increase the uptake and hence the efficiency of the soil-applied material $[1,8,11]$. This application technique is especially useful for micronutrients, but can also be used for major nutrients such as $\mathrm{N}, \mathrm{P}$ and $\mathrm{K}$. The amount that can be applied at any one time is small and thus it requires several applications to meet the needs of a crop for these nutrients. However, plant response is dependent on species, fertilizer form, concentration, and frequency of application, as well as the stage of plant growth. The increased efficiency can reduce the need for soil-applied fertilizer and reduce leaching and runoff of fertilizer nutrients, reducing the environmental impact of fertilizer salts [14, 36, 44].

Recently, the application of industrial byproducts to soil (beet vinasse, byproducts of the two-step olive oil mill plants, etc.) has been considered a good environmental and agricultural practice for maintaining soil organic matter, reclaiming degraded soils and supplying plant nutrients [14, 16, 40,41]. According to recent studies, the addition of byproducts of the two-step olive oil mill plants (rich in humic acids), especially 
those obtained after the second centrifugation in the two-step process, is a product of great agricultural interest due mainly to its organic matter [32, 40,41]. In this byproduct, these humic acids arise during the process of obtaining the olive oil. In the original plant tissues there are polyphenols and these are oxidized during the process of production of the olive oil, giving rise to these humic substances.

Foliar application of humic acids positively affects the plant growth. In this respect, it affects the uptake of macroand micro-elements $[2,13,30]$ and biochemical effects such as respiration and photosynthesis $[23,25,46]$, protein and nucleic acid synthesis $[5,17,43]$, and modulates the activity of $\mathrm{H}^{+}$-ATPase of both plasmalema and tonoplast $\mathrm{H}^{+}$-ATPases [18, 24, 27].

However, we have not found studies that make reference to the application of these byproducts by foliar fertilization and their impact on maize yield. For this reason, the main objective of this work was to study the effect of foliar fertilization at different doses with a byproduct of the two-step olive oil mill process on the productivity and quality of maize crops, and to evaluate the utility of this byproduct for this crop.

\section{MATERIALS AND METHODS}

\subsection{Properties of the byproduct}

The general properties of the byproduct obtained after the second centrifugation in the two-step olive oil mill process are shown in Table I. The methodology for obtaining this byproduct is described in detail elsewhere [9]. In a summary, the byproduct obtained from the first centrifugation in the twostep process is subjected to a second centrifugation to extract residual oil. The results suggest that the byproduct of the second centrifugation is the most suitable in regard to soil permeability, seed germination and phosphorus contents [9].

\subsection{Site}

The study was conducted from March to September 2001 in Lora del Río, near Sevilla (Andalusia, Spain). The soil of the field experiment is a calcaric Fluvisol [6]. The main soil (0$25 \mathrm{~cm}$ ) characteristics are the following: $\mathrm{pH} 7.5$ determined in distilled water with a glass electrode (soil: $\mathrm{H}_{2} \mathrm{O}$ ratio $1: 1$ ), $0.3 \mathrm{~g} \cdot \mathrm{kg}^{-1}$ total $\mathrm{N}$ [15], $1.2 \mathrm{~g} \cdot \mathrm{kg}^{-1}$ total $\mathrm{C}$ (dry wt. basis) as determined by the dry combustion method [15], $2.3 \mathrm{mg} \cdot \mathrm{kg}^{-1}$ available $\mathrm{P}$ [8], $17.2 \mathrm{cmol} \cdot \mathrm{kg}^{-1}$ cationic exchange capacity [10], and clay $122 \mathrm{~g} \cdot \mathrm{kg}^{-1}$ soil, silt $143 \mathrm{~g} \cdot \mathrm{kg}^{-1}$ soil and sand $735 \mathrm{~g} \cdot \mathrm{kg}^{-1}$ soil (determined by the Robinson's pipette method; [34]).

\subsection{Experimental layout and treatments}

The experimental layout was a split-plot in a randomized complete block with a total amount of 12 plots, with each plot measuring $8 \mathrm{~m} \times 6 \mathrm{~m}$. Three treatments were used $(3$ replicates per treatment): (1) treatment A0, plots without foliar fertilizer; (2) treatment A1, plots foliar-fertilized with byproduct at a dose of $15 \mathrm{~cm}^{3} / 100 \mathrm{~L}$; (3) treatment A2, plots foliar-fertilized with
Table I. Average properties of the byproduct obtained after the second centrifugation in the two-step olive oil extraction process (oven dry basis $)^{\mathrm{a}}$. The analysis was performed by MAPA [20].

\begin{tabular}{lc}
\hline & Mean \pm standard error \\
\hline $\mathrm{pH}$ & $3.9 \pm 0.4$ \\
Density $\left(\mathrm{g} \cdot \mathrm{cm}^{-3}\right)$ & $1.18 \pm 0.07$ \\
Dry matter $\left(\mathrm{g} \cdot \mathrm{kg}^{-1}\right)$ & $285 \pm 24$ \\
Organic matter $\left(\mathrm{g} \cdot \mathrm{kg}^{-1}\right)$ & $150 \pm 18$ \\
Humic acid-C $\left(\mathrm{g} \cdot \mathrm{kg}^{-1}\right)$ & $87 \pm 6$ \\
Fulvic acid-C $\left(\mathrm{g} \cdot \mathrm{kg}^{-1}\right)$ & $0.64 \pm 0.10$ \\
$\mathrm{Kjeldahl}-\mathrm{N}\left(\mathrm{g} \cdot \mathrm{kg}^{-1}\right)$ & $10 \pm 2$ \\
$\mathrm{P}(\mathrm{g} \cdot \mathrm{kg}-1)$ & $8 \pm 1$ \\
$\mathrm{~K}\left(\mathrm{~g} \cdot \mathrm{kg}{ }^{-1}\right)$ & $40 \pm 6$ \\
$\mathrm{Ca}\left(\mathrm{mg} \cdot \mathrm{kg}^{-1}\right)$ & $910 \pm 27$ \\
$\mathrm{Mg}\left(\mathrm{mg} \cdot \mathrm{kg}^{-1}\right)$ & $440 \pm 31$ \\
$\mathrm{Fe}\left(\mathrm{mg} \cdot \mathrm{kg}^{-1}\right)$ & $470 \pm 66$ \\
$\mathrm{Cu}\left(\mathrm{mg} \cdot \mathrm{kg}^{-1}\right)$ & $4.9 \pm 0.8$ \\
$\mathrm{Mn}\left(\mathrm{mg} \cdot \mathrm{kg}^{-1}\right)$ & $5.4 \pm 1.1$ \\
$\mathrm{Zn}\left(\mathrm{mg} \cdot \mathrm{kg}^{-1}\right)$ & $14 \pm 3$ \\
$\mathrm{Polyphenols}\left(\mathrm{g} \cdot \mathrm{kg}^{-1}\right)$ & $23 \pm 7$ \\
$\mathrm{Sugars}\left(\mathrm{g} \cdot \mathrm{kg}^{-1}\right)$ & $0.48 \pm 0.11$ \\
$\mathrm{Lipids}\left(\mathrm{g} \cdot \mathrm{kg}^{-1}\right)$ & $0.32 \pm 0.09$ \\
\hline
\end{tabular}

${ }^{\mathrm{a}}$ Data are the means of 7 samples.

byproduct at a dose of $30 \mathrm{~cm}^{3} / 100 \mathrm{~L}$, and (4) treatment $\mathrm{A} 3$, plots foliar-fertilized with byproduct at a dose of $50 \mathrm{~cm}^{3} / 100 \mathrm{~L}$. The foliar fertilizer (byproduct) was applied using a hand-held $\mathrm{CO}_{2}$ powered sprayer adjusted to a constant pressure of $0.017 \mathrm{MPa}$ (no other additives were used). The plots were sprayed during late afternoon or evening hours when wind speed was less than $7 \mathrm{~km} \cdot \mathrm{h}^{-1}$ and air temperature was less than $23{ }^{\circ} \mathrm{C}$.

Table II shows the irrigation plan carried out during the experiment for all treatments (common practice in the area) and the climatic characteristics of the study area. This irrigation was carried out by sprinklers. Independently of the irrigation that all plots received, the plants that were foliar-fertilized received the same quantity of water but different byproduct rates. The climatic characteristics of the study area are typical for a Mediterranean climate.

All plots were additionally fertilized with $300 \mathrm{~kg} \mathrm{~N} \cdot \mathrm{ha}^{-1}$ (as urea), $80 \mathrm{~kg} \mathrm{P} \cdot \mathrm{ha}^{-1}$ [as $\left.\left.\left(\mathrm{NH}_{4}\right) \mathrm{H}_{2} \mathrm{PO}_{4}\right)\right]$ and $120 \mathrm{~kg} \mathrm{~K} \cdot \mathrm{ha}^{-1}$ (as $\mathrm{K}_{2} \mathrm{SO}_{4}$ ), which is the common practice in the area. The mineral fertilizers were incorporated on 10 March 2001 to a 25-cm depth.

Maize (Zea mays, L. cv. Tundra) was sown at a rate of 100000 plants $\cdot \mathrm{ha}^{-1}$ in $75-\mathrm{cm}$ inter-row spacing, which is common practice in the area. The sowing date was 19 March 2001. Prophylactic applications of herbicide (MCPA) and herbicide insecticide ( $\alpha$-cipermethrine) were applied.

Foliar treatments were applied four times, from 15 April to 30 August 2001 (15 April, 14 May, 16 June and 14 July). Visual ratings of leaf injury due to the fertilizer application were 
Table II. Irrigation plan carried out and climatic characteristics during the experiment.

\begin{tabular}{|c|c|c|c|c|}
\hline \multicolumn{3}{|c|}{ Irrigation plan } & \multicolumn{2}{|c|}{ Climatic characteristics } \\
\hline Week & $\begin{array}{c}\text { No. } \\
\text { irrigation }\end{array}$ & $\mathrm{m}^{3}$ & $\begin{array}{c}\text { rainfall } \\
\left(\mathrm{m}^{3}\right)\end{array}$ & $\begin{array}{c}\text { air temperature } \\
\left({ }^{\circ} \mathrm{C}\right)\end{array}$ \\
\hline 1 (sowing) & 3 & 42 & 0 & 16.3 \\
\hline 2 & 3 & 42 & 0 & 16.5 \\
\hline 3 & 3 & 52 & 0 & 16.6 \\
\hline 4 & 3 & 88 & 8.7 & 16.2 \\
\hline 5 & 3 & 120 & 5.3 & 15.8 \\
\hline 6 & 3 & 150 & 0 & 16.0 \\
\hline 7 & 3 & 165 & 0 & 16.4 \\
\hline 8 (maize was $40 \mathrm{~cm}$ high) & 3 & 185 & 4.5 & 16.2 \\
\hline 9 & 3 & 190 & 0 & 19.5 \\
\hline 10 & 3 & 230 & 8.1 & 18.3 \\
\hline 11 & 3 & 250 & 2.3 & 19.0 \\
\hline 12 & 3 & 230 & 0 & 19.4 \\
\hline $\begin{array}{l}13 \\
\text { (maize was } 70 \mathrm{~cm} \text { high) }\end{array}$ & 3 & 220 & 3.4 & 21.2 \\
\hline 14 & 3 & 200 & 2.5 & 23.4 \\
\hline 15 & 3 & 192 & 0 & 24.5 \\
\hline 16 & 3 & 192 & 4.8 & 26.1 \\
\hline 17 & 3 & 192 & 0 & 27.2 \\
\hline 18 & 3 & 192 & 0 & 27.8 \\
\hline 19 & 3 & 190 & 0 & 28.3 \\
\hline 20 (tasseling) & 3 & 190 & 0 & 28.9 \\
\hline 21 & 3 & 160 & 0 & 29.8 \\
\hline 22 & 3 & 140 & 0 & 30.4 \\
\hline 23 & 3 & 120 & 0 & 32.3 \\
\hline 24 & 3 & 100 & 0 & 30.5 \\
\hline 25 & 2 & 95 & 0 & 27.0 \\
\hline 26 & 2 & 90 & 0 & 26.9 \\
\hline 27 & 2 & 80 & 10.8 & 26.0 \\
\hline 28 & 2 & 70 & 2.3 & 26.1 \\
\hline 29 (harvest) & 1 & 65 & 0 & 23.8 \\
\hline
\end{tabular}

collected from all trials by two independent observers. Leaf injury was expressed as the percentage of leaf area damaged. Potential treatment effects on the duration of green leaf area were estimated by visual ratings of the proportion of green and yellow leaves before leaf drop began.

Triplicate leaf samples were taken from each of the plots at four stages during the maize growth cycle: (i) when the maize was $40 \mathrm{~cm}$ high, 2 May 2001; (ii) when the maize was $70 \mathrm{~cm}$ high, 10 June 2001; (iii) at tasseling, 27 July 2001, and (iv) at harvest, 28 September 2001, by selecting the spike leaves for the dates. The aerial parts of eight plants were collected from all replications of the same treatments at the same growth stage. Leaf samples were washed, frozen in a liquid $\mathrm{N}_{2}$ and stored in a freezer at $20^{\circ} \mathrm{C}$ until analyzed. Leaf samples were mineralized [3] and subjected to the following analyses: $\mathrm{K}, \mathrm{Ca}$,
$\mathrm{Mg}, \mathrm{Fe}, \mathrm{Cu}, \mathrm{Mn}$ and $\mathrm{Zn}$ by atomic absorption spectrophotometry; P by the Williams and Stewart method, described by [10], and $\mathrm{N}$ by the Kjeldahl method [20] on fresh matter. Chlorophylls and total carotenoids in the lyophilized leaf samples were measured by extraction with methanol and quantified by the Lichtenthaler method [12]. Leaf soluble carbohydrate contents were measured using the anthrone method [45]. About $50 \mathrm{~g}$ samples were collected from each plot. Dried leaf samples were extracted in $5 \mathrm{~cm}^{3} 80 \%$ (v/v) ethanol (30 min, $\left.30{ }^{\circ} \mathrm{C}\right)$. The extract was centrifuged $(10 \mathrm{~min}, 2650 \times \mathrm{g})$ and the pellet was extracted again with ethanol. After centrifugation, chlorophyll was removed from the combined supernatants by chloroform extraction. The samples were analyzed colorimetrically for soluble carbohydrates using the anthrone method.

Crop yield $\left(\mathrm{kg} \cdot \mathrm{ha}^{-1}\right)$, number of grains per corncob and protein content [20] were determined on samples collected in each plot on 28 September 2001. Grain mineral composition was characterized by analyzing $\mathrm{N}, \mathrm{P}, \mathrm{K}, \mathrm{Ca}, \mathrm{Mg}, \mathrm{Fe}, \mathrm{Cu}, \mathrm{Mn}$ and $\mathrm{Zn}$ by techniques described previously. Also, grain soluble carbohydrate contents were characterized by a technique described previously.

\subsection{Statistical analysis}

Analysis of variance was performed on leaf mineral nutrient and soluble carbohydrate contents, chemical composition of pigments, grain mineral nutrient and soluble carbohydrate contents, and protein content and crop yield parameters' response to foliar byproduct fertilizer using the PROC MIXED procedure in the Statgraphics v. 5.0 software package [35] and considering the treatment as the independent variable. The means were separated by the Tukey's test, considering a significance level of $P<0.05$ throughout the study.

\section{RESULTS AND DISCUSSION}

\subsection{Leaf injury and plant maturity}

The foliar fertilization treatments produced little leaf injury and, therefore, the results are not shown. The A1 and A2 treatments produced no visual injury in any trial. The A3 treatment produced moderate leaf injury because of the acid $\mathrm{pH}$ of the byproduct. This byproduct has a very high capacity buffer [9], and therefore, when mixing $50 \mathrm{~cm}^{3}$ of the byproduct with $100 \mathrm{~L}$ of water (treatment A3), the dissolution continues, presenting an acid $\mathrm{pH}$. Since the quantity of byproduct used in this treatment is bigger, and due to this $\mathrm{pH}$ characteristic, when applying by foliar fertilization on the plant, the structures of some cells are damaged. The percentage of leaf area affected was only $4 \%$ or less. Foliar fertilization did not affect the maturity of the maize plants and, therefore, the data are not shown.

\subsection{Leaf mineral nutrient content of the maize growth cycle}

Table III shows the dynamics of leaf mineral contents during the maize cycle, expressed on a dry matter basis. The A3 treatment had the highest leaf average $\mathrm{N}$ levels for the first 
Table III. Leaf mineral nutrient content of the maize growth cycle (on a dry matter basis).

\begin{tabular}{|c|c|c|c|c|c|c|c|c|c|}
\hline & $\mathrm{N}^{\dagger}$ & $\mathrm{P}$ & $\mathrm{K}$ & $\mathrm{Ca}$ & $\mathrm{Mg}$ & $\mathrm{Fe}$ & $\mathrm{Mn}$ & $\mathrm{Cu}$ & $\mathrm{Zn}$ \\
\hline & \multicolumn{5}{|c|}{$\left(\mathrm{g} \cdot \mathrm{kg}^{-1}\right)$} & \multicolumn{4}{|c|}{$\left(\mathrm{mg} \cdot \mathrm{kg}^{-1}\right)$} \\
\hline \multicolumn{10}{|c|}{ maize was $40 \mathrm{~cm}$ high (2 May) } \\
\hline A0 treatment & 34.7 & 2.4 & 41.0 & 7.6 & 6.4 & 448 & 63 & 10 & 33 \\
\hline A1 treatment & 35.9 & 2.5 & 42.6 & 7.7 & 6.2 & 450 & 62 & 11 & 35 \\
\hline A2 treatment & 36.4 & 2.5 & 43.7 & 7.8 & 6.2 & 453 & 60 & 11 & 36 \\
\hline A3 treatment & 37.2 & 2.6 & 44.9 & 7.8 & 6.1 & 459 & 59 & 12 & 38 \\
\hline \multicolumn{10}{|c|}{ maize was $70 \mathrm{~cm}$ high (10 June) } \\
\hline A0 treatment & 33.8 & 2.2 & 39.7 & 7.7 & 5.9 & 438 & 64 & 11 & 34 \\
\hline A1 treatment & 34.4 & 2.3 & 40.1 & 7.8 & 6.0 & 441 & 61 & 12 & 36 \\
\hline A2 treatment & 35.3 & 2.3 & 40.9 & 7.9 & 6.0 & 446 & 60 & 12 & 37 \\
\hline A3 treatment & 35.9 & 2.4 & 41.2 & 7.9 & 6.1 & 450 & 58 & 13 & 39 \\
\hline \multicolumn{10}{|c|}{ tasseling (27 July) } \\
\hline A0 treatment & 29.4 & 2.0 & 24.1 & 7.9 & 3.7 & 356 & 79 & 11 & 36 \\
\hline A1 treatment & 30.1 & 2.1 & 24.6 & 8.2 & 3.4 & 364 & 72 & 12 & 39 \\
\hline A2 treatment & 30.8 & 2.2 & 25.3 & 8.3 & 3.3 & 371 & 70 & 13 & 40 \\
\hline A3 treatment & 31.8 & 2.2 & 26.1 & 8.4 & 3.2 & 379 & 69 & 14 & 42 \\
\hline \multicolumn{10}{|c|}{ harvest (28 September) } \\
\hline A0 treatment & 14.3 & 1.8 & 10.9 & 8.1 & 2.9 & 317 & 86 & 10 & 37 \\
\hline A1 treatment & 16.1 & 1.9 & 11.8 & 8.5 & 3.1 & 324 & 83 & 11 & 41 \\
\hline A2 treatment & 16.8 & 2.0 & 12.6 & 8.5 & 3.2 & 335 & 80 & 11 & 42 \\
\hline A3 treatment & 17.3 & 2.0 & 13.4 & 8.6 & 3.3 & 341 & 78 & 12 & 43 \\
\hline \multicolumn{10}{|c|}{ Average dates } \\
\hline A0 treatment & $28.1 \mathrm{a}^{\frac{\hbar}{t}}$ & $2.1 \mathrm{a}$ & $29.1 \mathrm{a}$ & $7.8 \mathrm{a}$ & $4.7 \mathrm{a}$ & $390 \mathrm{a}$ & $73 a$ & $10 \mathrm{a}$ & $35 \mathrm{a}$ \\
\hline A1 treatment & $29.1 b$ & $2.2 \mathrm{a}$ & $29.8 \mathrm{a}$ & $8.1 \mathrm{a}$ & $4.7 \mathrm{a}$ & $395 b$ & $69 b$ & $11 \mathrm{a}$ & $38 b$ \\
\hline A2 treatment & $29.8 \mathrm{c}$ & $2.3 \mathrm{a}$ & $30.6 \mathrm{~b}$ & $8.1 \mathrm{a}$ & $4.7 \mathrm{a}$ & $401 \mathrm{c}$ & $67 b$ & $12 \mathrm{a}$ & $39 b$ \\
\hline A3 treatment & $30.6 \mathrm{~d}$ & $2.3 \mathrm{a}$ & $31.4 \mathrm{c}$ & $8.2 \mathrm{a}$ & $4.8 \mathrm{a}$ & $408 \mathrm{~d}$ & $66 \mathrm{~b}$ & $13 \mathrm{a}$ & $41 c$ \\
\hline
\end{tabular}

${ }^{\dagger}$ Fresh matter. ${ }^{\ddagger}$ Letters were assigned to show treatment means separation at the 0.05 probability level. Within columns, identical lowercase letters indicate no significant difference between treatments.

data (2 May). The average values of $\mathrm{N}$ in leaves for the fertilizer treatments were higher than those of [32] after the application of $15 \mathrm{t} \cdot \mathrm{ha}^{-1} \cdot \mathrm{yr}^{-1}$ of this byproduct to soil. The statistical analysis indicated that significant differences existed with regard to fertilizer treatments. This increase in plant $\mathrm{N}$ in the plots fertilized with humic substances coincided with the results of $[4,8,19,30,37]$ on green asparagus crop, [22] on oat plants, and [31] on pumpkin plants, where the humic substances resulted in increased plant $\mathrm{N}$. Leaf $\mathrm{N}$ levels decreased gradually during the maize cycle, because of $\mathrm{N}$ transfers from leaves to spikes and grains for protein synthesis. Absolute values observed at the different stages suggest that crop $\mathrm{N}$ nutrition was adequate $[32,39]$.

The highest values of $\mathrm{P}, \mathrm{Ca}$ and $\mathrm{Mg}$ were observed in plots treated with the highest dose of byproduct, although differences were not statistically significant. Like $\mathrm{N}$, the average values of $\mathrm{P}, \mathrm{Ca}$ and $\mathrm{Mg}$ in leaves for the fertilizer treatments were higher than those of [32]. Lastly, an interaction was observed between $\mathrm{P}$ and $\mathrm{N}$, coinciding with [38, 40, 42].
The A3 treatment had the highest leaf average $\mathrm{K}$ levels. Like $\mathrm{N}$, the average values of $\mathrm{K}$ in leaves for the fertilizer treatments were higher than those of [32] after the application of $15 \mathrm{t} \cdot \mathrm{ha}^{-1} \cdot \mathrm{yr}^{-1}$ of this byproduct to soil. The statistical analysis indicated that significant differences existed with regard to fertilizer treatments. This higher $\mathrm{K}$ content may exert a beneficial effect on maize produced on these plots as this element has had a positive influence on the transfer of carbohydrates to the corncob [32,39], and improves the yield by more efficient grain filling [21].

With respect to micronutrients, the highest values were observed in plots foliar-fertilized with a higher dose of byproduct, except for the Mn, mainly due to the antagonistic effect of this micronutrient with $\mathrm{Fe}[40,41]$. Like macronutrients, the average values of micronutrients in leaves for the fertilizer treatments were higher than those of [32] after the application of this byproduct to soil. The statistical analysis indicated significant differences in $\mathrm{Fe}$ and $\mathrm{Zn}$ with respect to fertilizer treatments. This increased plant $\mathrm{Fe}$ and $\mathrm{Zn}$ in the 
plots fertilized with humic substances coincided with the results of $[3,8,13,15,26,30]$. These results indicate that foliar fertilization with humic substances may be helpful in soils that are deficient in $\mathrm{Fe}$ or $\mathrm{Zn}$.

\subsection{Leaf pigments and soluble carbohydrates analysis}

Table IV shows the leaf pigments and soluble carbohydrate contents during the maize cycle. The statistical analysis indicated significant differences in leaf pigments and soluble carbohydrate contents with respect to fertilizer treatments. The highest values of chlorophyll A and B, carotenoids and soluble carbohydrate contents were obtained in the foliar-fertilized plots, mainly where there was a higher supply of byproduct, according to [7, 8, 33]. Leaf pigments and soluble carbohydrate contents increased gradually during the maize cycle until harvest (28 September). Starting from this date, these values in the leaf decreased. These results are of great importance, because photosynthesis could be increased over a longer period of time as the levels of pigments in the leaf increase, resulting in a higher production of soluble carbohydrates and thereby increased yield and grain quality (Tab. VI). These results are in line with [8].

\subsection{Chemical analysis of the grains, grain soluble carbohydrates, protein content and crop yield parameters}

Table $\mathrm{V}$ shows the chemical analysis of the grains from the different treatments. The average values of chemical analysis of the grains for the fertilizer treatments were higher than those of [32] after the application of $15 \mathrm{t} \cdot \mathrm{ha}^{-1} \cdot \mathrm{yr}^{-1}$ of this byproduct to soil. The most significant differences were found in $\mathrm{N}$ and $\mathrm{P}$. For these macronutrients, the highest values were observed with the A3 treatment. The P levels were lower and the $\mathrm{N}$ levels higher than the values previously reported [39]. The K, Ca and Mg levels did not show any significant differences with the fertilizer treatments and their values were lower than the values reported by [32] for the same maize variety. These values were higher in the A 3 treatment. With respect to the analyzed micronutrients, the most significant differences were observed in Fe and $\mathrm{Zn}$. For these micronutrients, the highest values were observed with the A3 treatment. With respect to the grain soluble carbohydrate contents, the highest values were observed in the plots foliar-fertilized with a higher dose of byproduct. This may be due to transfers of soluble carbohydrates from leaves to grains, coinciding with [28, 29].
Table IV. Leaf pigments and soluble carbohydrate contents.

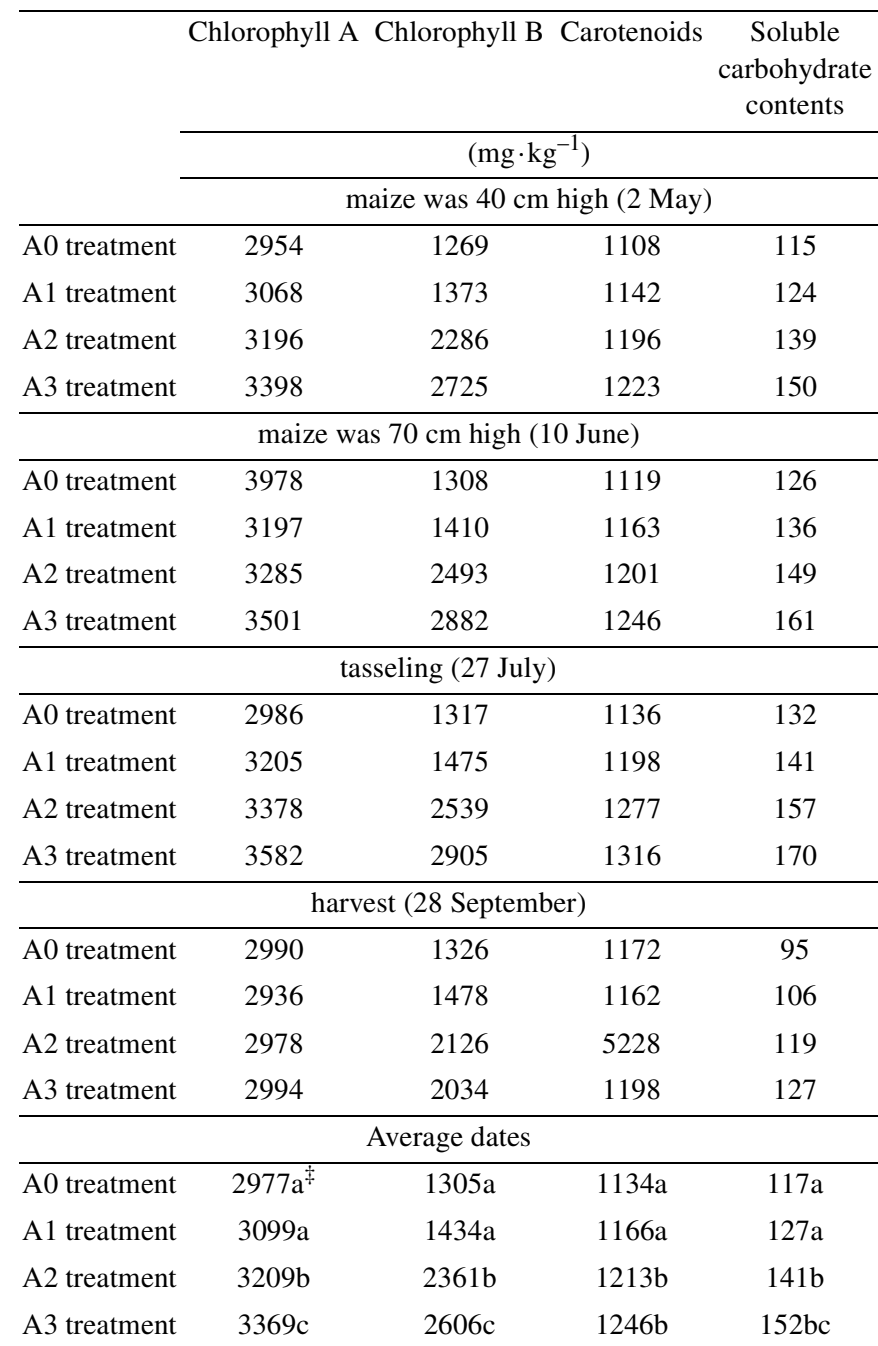

₹ Letters were assigned to show treatment means separation at the 0.05 probability level. Within columns, identical lowercase letters indicate no significant difference between treatments.

Table VI shows the protein content and crop yield parameters for the different treatments. The average values of protein content and crop yield parameters for the fertilizer treatments were higher than those of [32] after the application of this byproduct to soil. The highest protein content was in the

Table V. Chemical analysis of the grains.

\begin{tabular}{|c|c|c|c|c|c|c|c|c|c|c|}
\hline & $\mathrm{N}$ & $\mathrm{P}$ & $\mathrm{K}$ & $\mathrm{Ca}$ & $\mathrm{Mg}$ & $\mathrm{Fe}$ & $\mathrm{Mn}$ & $\mathrm{Cu}$ & $\mathrm{Zn}$ & SCC \\
\hline & \multicolumn{5}{|c|}{$\left(\mathrm{g} \cdot \mathrm{kg}^{-1}\right)$} & \multicolumn{4}{|c|}{$\left(\mathrm{mg} \cdot \mathrm{kg}^{-1}\right)$} & $\left(\mathrm{mg} \cdot \mathrm{kg}^{-1}\right)$ \\
\hline A0 treatment & $13.6 a^{\ddagger}$ & $2.3 \mathrm{a}$ & $4.3 \mathrm{a}$ & $0.3 \mathrm{a}$ & $0.9 a$ & $17.6 \mathrm{a}$ & $11.5 \mathrm{a}$ & $3.2 \mathrm{a}$ & $19.6 \mathrm{a}$ & $179 a$ \\
\hline A1 treatment & $14.7 \mathrm{ab}$ & $2.5 \mathrm{a}$ & $4.4 \mathrm{a}$ & $0.4 \mathrm{a}$ & $1.0 \mathrm{a}$ & $18.3 \mathrm{ab}$ & $11.4 \mathrm{a}$ & $3.3 \mathrm{a}$ & $20.8 \mathrm{a}$ & $198 \mathrm{ab}$ \\
\hline A2 treatment & $15.6 b$ & $2.9 \mathrm{ab}$ & $4.6 \mathrm{a}$ & $0.4 \mathrm{a}$ & $1.0 \mathrm{a}$ & $19.6 b$ & $11.3 \mathrm{a}$ & $3.3 \mathrm{a}$ & $21.7 \mathrm{ab}$ & $211 b$ \\
\hline A3 treatment & $16 . \mathrm{b} 8 \mathrm{c}$ & $3.2 \mathrm{~b}$ & $4.6 \mathrm{a}$ & $0.4 \mathrm{a}$ & $1.1 \mathrm{a}$ & $21.2 \mathrm{bc}$ & $11.3 \mathrm{a}$ & $3.4 \mathrm{a}$ & $22.6 b$ & $226 b c$ \\
\hline
\end{tabular}

SCC: soluble carbohydrate contents.

$\stackrel{+}{\dagger}$ Letters were assigned to show treatment means separation at the 0.05 probability level. Within columns, identical lowercase letters indicate no significant difference between treatments. 
Table VI. Protein content and crop yield parameters.

\begin{tabular}{|c|c|c|c|}
\hline & Protein content $(\%)$ & No grains corncob ${ }^{-1}$ & Yield $\left(\mathrm{kg} \cdot \mathrm{ha}^{-1}\right)$ \\
\hline A0 treatment & $8.5 \mathrm{a}^{\ddagger}$ & $457 \mathrm{a}$ & $11357 \mathrm{a}$ \\
\hline A1 treatment & $9.2 \mathrm{ab}$ & $498 b$ & $13002 b$ \\
\hline A2 treatment & $9.8 \mathrm{~b}$ & $536 \mathrm{c}$ & $13879 b$ \\
\hline A3 treatment & $10.5 b c$ & $589 \mathrm{~d}$ & $14875 \mathrm{c}$ \\
\hline
\end{tabular}

$\$$ Letters were assigned to show treatment means separation at the 0.05 probability level. Within columns, identical lowercase letters indicate no significant difference between treatments.

A3 treatment, while the lowest corresponded to the A1 treatment. The values were higher than those reported by [32] for the same maize variety fertilized with this byproduct applied to soil. The fertilizer treatments increased the number of grains per corncob, essentially when the highest rate was applied. Finally, maize yield increased significantly at each level of the byproduct.

\section{CONCLUSIONS}

There is great agricultural interest in olive oil mill byproduct as a soil additive, mainly due to its organic matter content and the improvement of soil physical, chemical and biological properties and increase in crop yield and quality [32, 40, 41]. However, this byproduct added to soil, while greatly improving its physical properties, needs a certain time to mineralize and supply the nutrient needed by the crops; moreover, a large quantity of product is needed to fulfil the nutritional requirement of the crops. Also, the dynamics of plant nutrient uptake are quite complex and are dependent on crop growth stages. There is a time lag between fertilizer application and the uptake of applied nutrient by plant roots. This is the reason why some authors suggest foliar fertilization for supplying the nutrients that the plant requires in the early stages of development.

In this study the mineral elements that were increased by foliar fertilization with the byproduct (rich in humic substances) were $\mathrm{Fe}, \mathrm{Zn}, \mathrm{N}$ and $\mathrm{K}$. The analysis of leaf pigments indicated the highest values of chlorophyll A and B, and carotenoids in the plots foliar-fertilized with this byproduct. Yield, grain number, grain protein content and grain soluble carbohydrate contents were all increased by foliar fertilization.

\section{REFERENCES}

[1] Asenjo M.C., Gonzalez J.L., Maldonado J.M., Influence of humic extracts on germination and growth of ryegrass, Commun. Soil Sci. Plant Anal. 31 (2000) 101-114.

[2] Chen Y., Aviad T., Effects of humic substances on plant growth, in: MacCarthy P., Clapp C.E., Malcolm R.L., Bloom P.R. (Eds.), Humic substances in soil and crop sciences, ASA and SSSA, Madison, WI, 1990, pp. 161-186.

[3] CIITDF, Métodos de referencia para la determinación de elementos minerales en vegetales, Ann. Edaf. Agrob. 28 (1969) 409-430.
[4] David P.P., Nelson P.V., Sanders D.C., A humic acid improves growth of tomato seedling in solution culture, J. Plant Nutr. 17 (1994) 173-184.

[5] Durante M., Attina E., Nardi S., Cacco G., Changes induced by humic substances and nitrate in the genomic structure of wheat roots, in: Senesi N., Miano T.M. (Eds.), 6th International Meeting of IHSS, Monopoli (Bari), 1992, 149 p.

[6] FAO/UNESCO, Carte mondiale des sols. Légende révisée, 60 FAO, 1989, $125 \mathrm{p}$

[7] Fortu, C., Rapsch S., Ascaso C., Action of humic acids preparations on leaf development mineral elements contents and chloroplast ultrastructure of ryegrass plants, Photosynthetica 19 (1985) 294-299.

[8] Gamiz R., Espejo J.A., Tejada M., Dobao M.M., Gonzalez J.L., Evolución de los contenidos de clorofilas en plantas de espárrago verde (Asparagus officinalis L.) tras la adición de aminoácidos y ácidos húmicos, in: Universidad Autónoma Madid (Ed.), Actas del VII Simposio Nacional-III Ibérico sobre Nutrición Mineral de las Plantas 1, 1998, pp. 173-178.

[9] Gomez M., Utilización de alpeorujo en la fabricación de abonos orgánicos y organominerales, Proyecto Fin de Carrera, EUITA, Universidad de Sevilla, España, 2000.

[10] Guitian F., Carballas T., Técnicas de análisis de suelos, Picro Sacro, Santiago de Compostela, España, 1976.

[11] Haq M.U., Mallarino A.P., Soybean yield and nutrient composition as affected by early-season foliar fertilization, Agron. J. 92 (2000) 16-24.

[12] Lichtenthaler H.K., Chlorophylls and carotenoids: Pigments of photosyntesis biomembranes, Method. Enzim. 148 (1987) 350383.

[13] Lobartini J.C., Orioli G.A., Absorption of iron-humate in nutrient solutions by plants, Plant and Soil 106 (1988) 153-157.

[14] Ludders P., Simon P., Foliar nutrition in orchard 1965-1979, Universitatsbibliotek der Technischen Universitat, Berlin, 1980.

[15] Mackowiak C.L., Grossl P.R., Bugbee B.G., Beneficial effects of humic acid on micronutrient availability to wheat, Soil Sci. Soc. Am. J. 65 (2001) 1744-1750.

[16] Madejon E., Aprovechamiento agronómico de composts de vinaza: Efectos en suelos, cultivos y aguas de drenaje, Ph.D. thesis, Universidad de Sevilla, España, 1996.

[17] Maggioni A., Varanini Z., Nardi S., Pinton, R., Action of soil humic matter on plant roots: stimulation of ion uptake and effects on $\left(\mathrm{Mg}^{2+}+\mathrm{K}^{+}\right)$ATPase activity, Sci. Total Environ. 62 (1987) 355-363.

[18] Maggioni A., Varanini Z., Pinton R., De Biasi M.G., Humic substances affect transport properties of root membranes, in: Kubat J. (Ed.), Elsevier, Amsterdam, 1992, pp. 137-144.

[19] Malik A., Azam F., Effects of humic acid on wheat (Triticum aestivum L.) seedling growth, Environ. Exp. Bot. 25 (1985) 242-245.

[20] MAPA, Métodos oficiales de análisis, Secretaría Gral. Téc. del Ministerio de Agricultura, Pesca y Alimentación 1 (1986) 221285 .

[21] Mengel K., Seger M., Koch K., Potassium effect on protein formation and amino acid turnove in developing wheat grain, Agron. J. 73 (1981) 74-78.

[22] Mishra B., Srivastava L.L., Physiological properties of humic acids isolated from some major soil associations of Bihar, J. Indian Soc. Soil Sci. 36 (1988) 83-89.

[23] Nardi S., Concheri G., Dell'Agnola G., Scrim P., Nitrogen uptake and ATPase activity in oat seedlings in the presence of two humic fractions, Soil Biol. Biochem. 23 (1991) 833-836.

[24] Pasqualoto L., Lopes F., Okorokova-Façanha A.L., Rocha A., Humic acids isolated from eartworm compost enhance root elongation, lateral root emergence, and plasma membrane $\mathrm{H}^{+}$-ATPase activity in maize roots, Plant Physiol. 130 (2002) 1951-1957. 
[25] Passera C., Nicolao L., Ferretti M., Rascio N., Ghisi R., Effect of humic substances on enzyme activities of sulphate assimilation and chloroplast ultrastructure of maize leaves, Photosynthetica 25 (1991) 39-45.

[26] Piccolo A., Pietramellara G., Celano G., Iron extractability from iron-humate complexes by a siderophore and a mixture of organic acids, Can. J. Soil Sci. 73 (1993) 293-298.

[27] Pinton R., Varanini Z., Vizzotto G., Maggioni A., Soil humic substances affect properties of tonoplast vesicles isolated from oat roots, Plant and Soil 142 (1992) 203-210.

[28] Rajcan I., Dwyer L.M., Tollenaar M., Note on relationship between leaf soluble carbohydrate and chlorophyll concentrations in maize during leaf senescence, Field Crop. Res. 63 (1999) 13-17.

[29] Rajcan I., Tollenaar M., Source: sink ratio and leaf senescence in maize: II. Nitrogen metabolism during grain filling, Field Crop. Res. 60 (1999) 255-265.

[30] Rauthan B.S., Schnitzer M., Effects of soil humic acid on the growth and nutrient content of cucumber (Cucumis sativus) plants, Plant and Soil 63 (1981) 491-495.

[31] Rzaev N.M., Mardonova N.B., Bondar N.K., Effectiveness of humic acids in relation to the status of nitrogen nutrition (of pumpkin), Izv. Akad. Nauk. Az. SSR, Ser. Biol. Nauk. 3 (1989) 29-34.

[32] Salgado E., Primeros resultados de la aplicación de alpeorujo en un cultivo de maíz (Zea mays L.), Proyecto Fin de Carrera, EUITA, Universidad de Sevilla, España, 2000.

[33] Sladky Z., Effect of humic acids on the growth of isolated roots, Proc. Int. Symp. Humus et Planta IV, Prague, 1967, pp. 286-287.

[34] SSEW, Soil Survey Laboratory methods, H.B. No. 6, Harpenden, 1982, p. 60.

[35] Statistical Graphics Corporation, Statgraphics 5.0. Statistical Graphics System, Educational Institution Edition, USA, 1991, $105 \mathrm{p}$.
[36] Suwaranit A., Sestapukdee M., Stimulating effects of foliar Kfertilizer applied at the appropriate stage of development of maize: A new way to increase yield and improve quality, Plant and Soil 120 (1989) 106-111.

[37] Tattini M., Chiarini A., Tafani R., Castagneto M., Effect of humic acids on growth and nitrogen uptake of container-grown olive (Olea europea L. Maurino), Acta Hortic. 286 (1990) 125-128.

[38] Tejada M., Influencia de la adición de abonos orgánicos y organominerales en las características de suelos y cultivos, Ph.D. Thesis, Universidad de Córdoba, España, 1996.

[39] Tejada M., Benitez C., Gonzalez J.L., Nutrición mineral del maíz, Phytoma 39 (1992) 16-23.

[40] Tejada M., Ordoñez C., Gonzalez J.L., Utilization of a byproduct of the two-step olive oil mill process on wheat yield under dryland conditions, Agrochimica 45 (2001) 199-206.

[41] Tejada M., Gonzalez J.L., Application of a byproduct of the twostep olive oil mill process on rice yield, Agrochimica (2003) in press.

[42] Teng Y., Timmer R., Nitrogen and phosphorus in an intensively managed nursery soil-plant system, Soil Sci. Soc. Am. J. 58 (1994) 232-237.

[43] Vaughan D., Malcolm R.E., Influence of humic substances on growth and physiological processes, in: Vaughan D., Malcolm R.E. (Eds.), Soil organic matter and biological activity, Martinus Njihoff/Dr. W. Junk Publishers, Dordrecht, 1985, pp. 37-75.

[44] Venugoplan M.V., Tarhalmar P.P., Singh J., Efficacy of phosphate carriers as foliar fertilizer on rainfed upland cotton (Gossypium hirsitum), Indian J. Agric. Sci. 65 (1995) 320-328.

[45] Yemm E.W., Willis, A.J., The estimation of carbohydrate in plant extracts by anthrone, J. Biochem. 75 (1954) 508-514.

[46] Zimmerman A.P., Electron intensity, the role of humic acids in extracellular electron transport and chemical determination of $\mathrm{pH}$ in natural waters, Hydrobiologia 78 (1981) 259-265. 